\title{
Management of irrigation schemes in Algeria: an assessment of water policy impact and perspectives on development
}

\author{
K. Laoubi \& M. Yamao \\ Graduate School of Biosphere Science, Hiroshima University, Japan
}

\begin{abstract}
To enhance the performance of irrigation schemes, the Algerian government has adopted significant reforms. Structural reform has involved the decentralization of water resource management and the establishment of an autonomous irrigation agency. Regulatory reform has focused on water pricing with the goal of cost recovery. In addition, the government earmarked public investment for a ten-year integrated water resource management initiative. Hence, the general objective of this paper is to assess the effects of water reforms on the performance of irrigation scheme management in Algeria. We used various performance indicators to evaluate two selected irrigation schemes: the East and West Mitidja. The results showed that the water policy implemented did not create a sustainable environment for the irrigation schemes. The lack of coordination between water agencies has led to poor monitoring of scarce watersupply services. Furthermore, the weak involvement of stakeholders as well as the indifference of local administrations exacerbated irrigation management issues. The water price did not reflect the total cost of supply, and the maintenance budgets in both irrigation schemes are below international and regional norms. This contributed to the deterioration of irrigation infrastructure, to greater water conveyance losses and to reduced delivery efficiency. Many factors were found to affect irrigation sustainability, such as fee collection constraints, water allocation constraints, land reform, disputes among members of the collective farms, inadequacy of the irrigation system components with regard to farm configuration, water theft, and acts of vandalism on the hydromechanic equipment. These constraints led to low equilibrium cycles for both schemes.
\end{abstract}

Keywords: Algeria, water policy, irrigation schemes management, water management, sustainability. 


\section{Introduction}

Water resources in Algeria are very limited and unequally distributed in space and time. The country has one of the lowest per capita water supplies in the world. The renewable water resources in Algeria amount to $600 \mathrm{~m} 3$ per-capita per year [1], which is below the UN threshold for water poverty (1000 m3/year/ capita). Irrigated agriculture is still the largest water user in the country, using about $65 \%$ of all water resources. However, the increasing competition over scarce water resources due to rapid urbanization has become a severe constraint and a serious threat to irrigated agriculture sustainability. For decades, during the socialist era in Algeria, water management has been characterized by centralized planning and management, an absence of water policy, organizational instability, supply-based water management, inadequate budgets allocated to irrigation authorities, poor operation and maintenance, unsustainability, low-level irrigation facilities, low productivity, and low water- and land-use efficiency [2-7].

Since the 1980s, the government has embarked on a program to decentralize water sector management. Irrigation scheme management was taken over by the irrigation agencies (Office des Périmètres Irrigués) and was financed through water sales and state subsidies. Moreover, in 1996, Algerian water policymakers introduced the concept of integrated water resource management in the watershed. The policy is designed around three main principles: water is an economic good, it is scarce and vulnerable, and it is the responsibility of all. With the new water code of 1996, the water tariff was recognized as an important instrument to conserve water, improve water use efficiency, and to provide for the sustainability of irrigation schemes. The principle of cost recovery has been established, and the irrigation water prices (with a two-part tariff structure) increased in 1998 and 2005.

In 2000, the government earmarked public investment for a ten-year integrated water resource management initiative. All directorates related to the irrigation sector have been transferred to the new ministry of water resources (created in 2000), and a new National Plan for Water was put in place in 2005. The move established an action plan for implementing an integrated water resource management framework involving all stakeholders in the water sector. In the same year, a new water code was adopted, and new institutional arrangements for irrigation water resources were undertaken. These institutional arrangements restructured the irrigation agencies into one irrigation management body, the ONID (National Organization for Irrigation and Drainage), which was set up as a financially independent legal entity.

The water policy was meant to initiate the sustainable development of irrigated agriculture, to provide an incentive framework towards improving the efficiency of irrigation, to facilitate self-management, and to ensure the financial viability of irrigation schemes. Hence, the research questions of this study were specifically: (1) Did the water policy achieve the objective, that is, irrigation scheme viability? (2) What are the factors affecting the sustainable management 
of irrigation schemes? Therefore, the overall aim of this research study is to assess the impact of changes in water policy on irrigation scheme management in Algeria.

\section{Methodology}

Two irrigation schemes were selected for this study: East and West Mitidja, which are located in the most fertile region of northern Algeria. East and West Mitidja cover an agricultural area of 18,000 ha and 9,250 ha, respectively. Farmers in both schemes are classified in three groups: collective state farms, individual state farms, and private farms. The surface irrigation water for the East Mitidja scheme is provided by Hamiz dam, the Reghaia marsh, and the Boureah pumping station. The East Mitidja scheme has a total theoretical storage capacity of 33 million cubic meters. The West Mitidja scheme is supplied from El-Moustaqbal Dam with a total theoretical storage capacity of 188 million cubic meters. The main crops grown in both schemes comprise various orchards and assorted annual crops.

A selected set of performance indicators developed by the IWMI (International Water Management Institute) and IPTRID (International Program for Technology and Research in Irrigation and Drainage) were used for the assessment of irrigation scheme performance. Performance is assessed to determine progress relative to strategic goals, as an integral part of performanceoriented management; to evaluate the general health of a system; to clarify the impacts of intervention constraints; to better understand the determinants of performance; and to compare the performance of one system with others or with the same system over time [8].

In 2007, a database based on secondary data was established. Data were obtained from annual operation and maintenance reports, annual balance sheets (1999-2005) and irrigation reports (1988-2006) from the ONID irrigation agency. For analysis, we also used technical reports from ONID on hydroagricultural management and agricultural development of the Mitidja region.

The present study also includes a survey examining farmers' views, opinions, and comments on the irrigation management schemes. In addition, we recorded personal observations regarding the irrigation scheme sites and provide supplementary information on institutional investigations and irrigation management, obtained with the help of key informants. These informants included staff members from the Ministry of Water Resources, agricultural utilities, the Ministry of Agriculture, the National Agency for Irrigation and Drainage (ONID) and the National Agency of Dams and Large Transmission Mains (ANBT).

\section{Results and discussion}

The selected performance indicators allowed us to determine the success of water policy objectives. As shown in table 1, the recovery ratio is below the financial sustainability ratio, i.e., $100 \%$, for both schemes. The cost recovery 
Table 1: Water price, O\&M costs $/ \mathrm{m}^{3}$, and cost recovery ratio in the two schemes.

\begin{tabular}{|c|c|c|c|c|c|c|c|}
\hline & 1999 & 2000 & 2001 & 2002 & 2003 & 2004 & 2005 \\
\hline $\begin{array}{c}\text { Inflation rate } \\
(\%)\end{array}$ & 2.64 & 0.34 & 4.23 & 1.42 & 2.59 & 3.6 & 1.6 \\
\hline \multicolumn{8}{|c|}{ East Mitidja scheme } \\
\hline Water price (da) & 1.25 & 1.25 & 1.25 & 1.25 & 1.25 & 1.25 & 2.5 \\
\hline $\begin{array}{c}\text { O\&M costs/ } \\
\text { volume }\left(\mathrm{da} / \mathrm{m}^{3}\right)\end{array}$ & 5.78 & 6.83 & 10.56 & 36.5 & 23.23 & 8.3 & 4.7 \\
\hline $\begin{array}{c}* \text { Recovery ratio } \\
(\%)\end{array}$ & 24 & 23 & 16 & 6 & 14 & 22 & 90 \\
\hline \multicolumn{8}{|c|}{ West Mitidja scheme } \\
\hline Water price (da) & 1.25 & 1.25 & 1.25 & 1.25 & 1.25 & 1.25 & 2.5 \\
\hline $\begin{array}{l}* * \text { O\&M costs/ } \\
\text { volume }\left(\mathrm{da} / \mathrm{m}^{3}\right)\end{array}$ & 2.33 & 4.8 & 7.75 & $* * *$ & 4.94 & 4.70 & 9.38 \\
\hline $\begin{array}{c}\text { Recovery ratio } \\
(\%)\end{array}$ & 57 & 28 & 19 & $* * *$ & 33 & 30 & 31 \\
\hline
\end{tabular}

* Recovery ratio $(\%)=$ Gross revenue collected/ total O\&M costs.

** O\&M costs=Total management, operation and maintenance costs of providing the irrigation and drainage services, excluding capital expenditures and depreciation/renewals.

$* * *$ No irrigation.

ratio increased by $68 \%$ from 2004 to 2005 for the East Mitidja scheme and by only $1 \%$ for the West Mitidja scheme. Even with a $100 \%$ increase in the water price in 2005, the O\&M expenditure per cubic meter was still higher.

The financial unsustainability of the irrigation schemes is mainly due to the following factors:

\subsection{Lack of maintenance}

The lack of irrigation system maintenance is the root cause of low cost recovery. As shown in table 2, the maintenance budget ratio was found to be lower in West Mitidja, averaging 6.2\% of total O\&M costs during the period from 1999-2005. In East Mitidja, the maintenance budget ratio was found to be $10.7 \%$ of total O\&M costs during the same period. Nevertheless, the maintenance budget ratio was very low in both schemes. Approximately half of O\&M costs are spent on administrative and management activity, rather than maintenance (see table 2). In fact, maintenance is carried out only in the case of emergency, and no funds are available to replace those that have been depleted. During the period from 19992005 , the average maintenance cost per ha was found to be $\$ 40.51$ and $\$ 14.73$, in East and West Mitidja, respectively. This situation has led to a vicious circle of low maintenance/low recovery. Based on international and regional norms, estimated maintenance needs should be within the range of US\$100 to 150 per hectare equipped [9]. The lack of irrigation system maintenance in these schemes can also be explained by the revenue diversification measures adopted by the irrigation agency. Indeed, the agency has developed a sideline business which has helped to create new sources of income. These include works, services 
provided, and equipment sales. However, diversified revenue collection may have negatively impacted water users. The agency was less concerned with farmers' problems; in turn, farmers lost trust in agency services. Consequently, farmers relied less on surface water provided by the agency and therefore looked for other sources of water. As shown in table 3, during the period from 20032005, works and water revenue contributed most to turnover in East Mitidja. In West Mitidja, works and equipment sales contributed the most to turnover. This side business has become the major source of income in both schemes. However, these alternative revenue sources do not represent the true purpose of the agency, for which income has traditionally been based on fee collection and recovery.

Table 2: $\quad$ Level of maintenance activity in the irrigation schemes.

\begin{tabular}{|c|c|c|c|c|c|c|}
\hline \multirow{2}{*}{ Year } & \multicolumn{2}{|c|}{$\begin{array}{c}\text { Maintenance } \\
\text { budget ratio }\end{array}$} & \multicolumn{2}{c|}{$\begin{array}{c}\text { Personnel cost } \\
\text { ratio }\end{array}$} & \multicolumn{2}{c|}{$\begin{array}{c}\text { Maintenance costs } \\
\text { per ha (\$) }\end{array}$} \\
\cline { 2 - 7 } & E.M & W.M & E.M & W.M & E.M & W.M \\
\hline 1999 & 0.07 & 0.05 & 0.49 & 0.69 & 12.7 & 7.90 \\
\hline 2000 & 0.03 & 0.05 & 0.64 & 0.74 & 7.10 & 8.80 \\
\hline 2001 & 0.03 & 0.08 & 0.70 & 0.70 & 7.60 & 23.9 \\
\hline 2002 & 0.17 & ----- & 0.49 & ----- & 96.6 & ----- \\
\hline 2003 & 0.06 & 0.06 & 0.40 & 0.54 & 33.3 & 21.4 \\
\hline 2004 & 0.28 & 0.07 & 0.47 & 0.59 & 108.5 & 19.4 \\
\hline 2005 & 0.11 & 0.06 & 0.60 & 0.47 & 17.5 & 21.5 \\
\hline Average & 0.11 & 0.05 & 0.54 & 0.53 & 40.51 & 14.73 \\
\hline
\end{tabular}

E.M. =East Mitidja scheme, and W.M. =West Mitidja scheme.

Table 3: $\quad$ Turnover structure for each irrigation scheme (2003-2005).

\begin{tabular}{|c|c|c|c|c|}
\hline Turnover structure & Scheme & 2003 & 2004 & 2005 \\
\hline \multirow{2}{*}{$\begin{array}{c}\text { Water revenue } \\
(\%)\end{array}$} & E.M & 23.72 & 16.65 & 40.12 \\
\hline & W.M & 22.34 & 22.84 & 11.84 \\
\hline \multirow{2}{*}{$\begin{array}{c}\text { Works } \\
(\%)\end{array}$} & E.M & 60.61 & 75.62 & 52.67 \\
\hline & W.M & 44.06 & 36.37 & 85.78 \\
\hline \multirow[t]{2}{*}{ Service provided $(\%)$} & E.M & 15.67 & 7.73 & 7.21 \\
\hline & W.M & 0.65 & 6.35 & 0.03 \\
\hline \multirow[t]{2}{*}{ Equipment sales (\%) } & E.M & 0 & 0 & 0 \\
\hline & W.M & 32.95 & 34.44 & 2.35 \\
\hline Total $(\%)$ & For each scheme & 100 & 100 & 100 \\
\hline
\end{tabular}

* E.M. =East Mitidja scheme, and W.M. =West Mitidja scheme.

* Works and service provided are mainly contracted works with government institutions such as DHW, DSA, etc., as well as interventions for the benefits of farmers.

* Equipment sales mainly refer to irrigation equipment such as sprinklers, etc. 


\subsection{Low conveyance efficiency}

Both irrigation systems are characterized by low conveyance efficiency (see figure1). Although the West Mitidja scheme is newer (built in 1988) than the East Mitidja scheme (built in 1935), the West Mitidja scheme displayed high losses in water conveyance. On average, the water losses in both schemes were found to exceed $30 \%$ during the period from 1999-2004 and $49 \%$ during the period from 2005-2006.

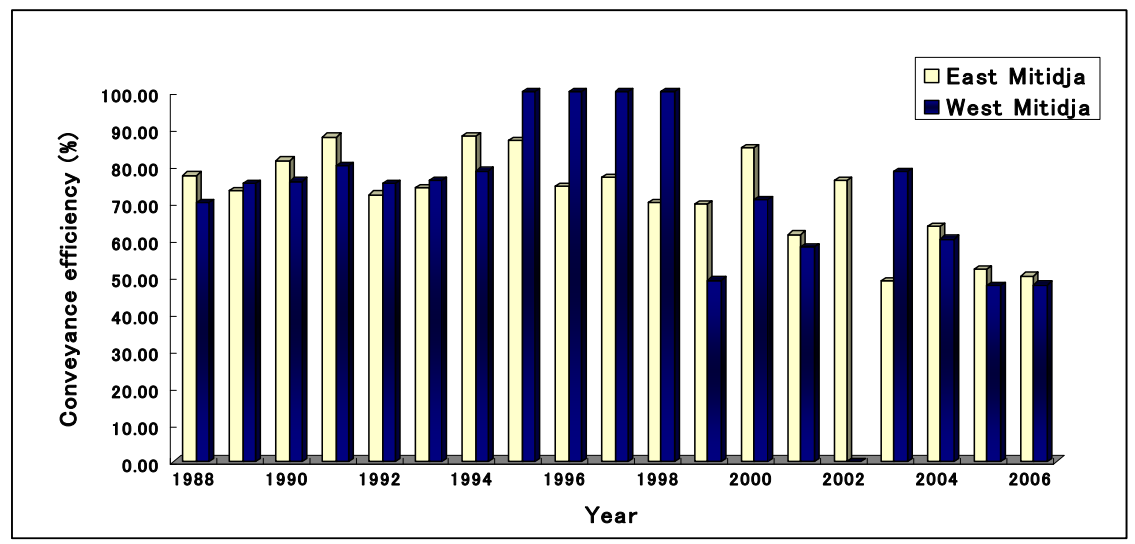

Figure 1: $\quad$ Conveyance efficiency in East and West Mitidja schemes (19882006). Conveyance efficiency $=$ Volume delivered $* 100 /$ Volume diverted.

The reduced level of conveyance efficiency in both schemes resulted from numerous reasons such as:

* The general age of the irrigation system, particularly in the East Mitidja scheme.

* The frequent stoppage of water release without advance notice resulted in repetitive damage to the irrigation network.

* Siltation of diversion weir, difficulties in performing maintenance on the intake structure, and reservoir cleaning during the flood.

* Lack of means to intervene in the irrigation system, increased rates of breakage, and deterioration of irrigation facilities.

* Acts of sabotage, vandalism, and theft downstream of dams as well as throughout the entire network; destruction of hydraulic equipment such as valves, suction, irrigation hydrants and water mains.

* Illegal use of water resources by farmers who connected to the irrigation system, and mishandling of valves by farmers, particularly in West Mitidja.

* Absence of water police and irrigators' associations, which can serve as counterweights to such practices. Moreover, the agency has no means of measuring the water present. Hence, the amount of water produced and water charges are estimated based on the quantities released and produced, 
respectively; irrigated areas; cultivation plans; and water consumption standards.

The factors mentioned above have had a negative impact on the efficiency of water distribution, as well as on farmers' irrigation management in the schemes. Indeed, according to farmers, when breakage occurred on the network, they waited more than two weeks and sometimes one month for the agency staff to start repairs, which sometimes never began. Consequently, the affected farmers have lost a proportion of their irrigation rates, resulting in yield losses.

Problems also occurred with public authorities. During the survey, three important breakages were caused by a private company working on behalf of the municipality located in the third section of the East Mitidja scheme. Therefore, the irrigation has been delayed and farmers were hesitant to cultivate annual crops. This situation showed a lack of coordination and illustrated the conflict of interest between ONID (irrigation management) and municipality (urbanization plan). Faced with uncertain water distribution, farmers reduced the irrigated areas. The volume of water in dams is so low that estimating the area to irrigate is risky; thus farmers tend to consume more of the water they receive on their farmlands. This problem has been exacerbated by the allocation of quotas among users.

\subsection{Fee collection constraints}

A structural constraint confronted by the irrigation agency is fee collection, particularity with farmers from the West Mitidja scheme. The lack of irrigation from 1995-1999 due to sabotage of the El Moustakbel dam and due to drought in 2002 contributed to the reluctance of farmers to use water provided by the agency. Indeed, the agency holds a claim of \$133,532 (in 31/03/2003) on farmers in West Mitidja. Despite this large amount of money and after processing farmers' files, the agency has provided a flexible payment schedule.

According to ONID, the level of fee collection averaged $75 \%$ during the period from 2002-2005. The level of fee collection is higher in the East Mitidja scheme, because there are fewer private boreholes/wells as compared to the West Mitidja scheme. According to ONID data, 37\% of farmers in West Mitidja but only $0.30 \%$ of farmers in East Mitidja own boreholes/wells. Therefore, the debts are more easily recoverable from the farmers in East Mitidja. Fee collection is also constrained by worsening irrigation management system "water turn" at the intake level. Intake use is shared among farmers; every farmer has an allotted time in the programmed water turn. It is therefore difficult to penalize farmers individually for non-payment of bills by stopping the water supply. If the intake gate is closed, all farmers will be penalized.

In addition, several other factors were found influencing the fee collection performance such as: poor availability of water services, sub-optimal utilization of bare land, disputes among members of the collective farms, state parcel lands leased to private farmers, inadequacy of the irrigation system for particular farm configurations, water theft during the night, and acts of vandalism on the hydromechanical equipment. 


\subsection{Water and land resource constraints}

Growing populations and associated urbanization, as well as drought, have considerably reduced the allocation of water resources to irrigated land [10]. The Hamiz and El Moustakbal dams provided water exclusively to Algiers City in 1988. Notably, 13 million $\mathrm{m}^{3}$ of water were supplied from the Hamiz dam to the Keddara dam in order to supply water for Algiers City. In 2002, an emergency plan was initiated to obtain water from both dams, resulting in a total volume of $16,745,528 \mathrm{~m}^{3}$ supplied to urban users, and no supply for the schemes. In 1988 and 2002, the only source of irrigation water for the East Mitidja scheme was the Reghaia marsh. Furthermore, the country's security situation in the 1990s ruined the El Moustakbel dam, and therefore prevented irrigation in the West Mitidja scheme for a period of 5 years. In addition, for the last 8 years, a declining water table has resulted in the allocation of Boureah pump stations to supply urban users.

Reductions in the availability of irrigated land have also been exacerbated by the land reform of 1987. The government converted state farms into either privately owned or collective farms. With land becoming lucrative, growing numbers of landholders have been selling their usufruct deeds even while their land was still state property. This has led to a significant decrease in the number of land users, as well as a decrease in the area under irrigation, particularly in the East Mitidja scheme [10]. About $18 \%$ of the total land area of the Mitidja East scheme has now been urbanized. In the West Mitidja scheme, less than $1 \%$ of irrigable land ( $54 \mathrm{ha}$ ) has been urbanized. Forecasts for urban population growth in the Mitidja region predicted that consumption of land between 1998 and 2005 would be over 11,000 hectares, reaching 32,000 hectares in 2025 [11].

\subsection{Constraints on the water allocation system}

\subsubsection{At the beginning of the irrigation season}

The volumes of water allocated by ONID to the irrigation schemes are estimated according to the needs expressed by farmers (volume contracted). The application process to secure permission for the use of water starts at the beginning of each irrigation season (usually in March). The user must submit his water demand to the agency, by specifying the number of hectares, the crop type, and volume of water desired. In parallel, there is a traditional survey performed by agency staff and ditch-riders, as well as by the heads of the irrigation system, in order to accurately record the land allocated to crop irrigation and cultivation. The irrigators' association may also intervene to express the needs of farmers and to support them during agency proceedings. At the end of the application period, the agency determines the volume of irrigation water per hectare per year for each crop, and may determine water turns. However at this stage, several constraints to effective irrigation management have been identified:

* The farmers are very weakly organized [12]. Field surveys indicate that only $3.7 \%$ of farmers in East Mitidja and $12.2 \%$ of farmers in West Mitidja are involved in farmers' organizations. 
* Indebted farmers settle their debt at the beginning of the irrigation season. This creates difficulties in managing claims and deprives the agency of resources to adequately prepare for the new irrigation season.

* Small crowds at the irrigation agencies, particularly in the West Mitidja scheme. Due to sabotage of the El Moustakbel dam in the 1990s, the number of wells/boreholes in the West Mitidja has increased significantly. The field survey indicated that more than $90 \%$ of farmers are using groundwater resources. In many cases, the wells/boreholes were drilled without authorization, and the authorities lacked the instruments for water management or law enforcement necessary to stop these activities. The consequences of illegal water use led to overexploitation and deterioration of the Mitidja aquifer. Moreover, the use of groundwater in the schemes did not provide any revenue to the scheme agency, reducing its financial sustainability.

\subsubsection{At the ministry level}

The ONID forwards the volume requested to the DHA Directorate of Irrigation (directorate of the Ministry of Water Resources) before the start of the irrigation season, i.e., April. The request is subsequently processed in the SDERHA (Subdirectorate of the Operation and Regulation of Agricultural Water Management). Determinations are made according to available storage in the dams, after subtracting the volume of water allocated to urban use. Notably, the DHA is updated weekly with information on dam water storage. Once the request is processed in the SDERHA, it is submitted to the head of the "Allocation Committee," as well as to other members, such as the head of DAEP (Potable Water Supply Directorate) and the head of DMRE (Water Resources Mobilization Directorate). The two directorates formulate their opinions and meet with the head of DHA and the general secretary of the Ministry of Water Resources. Meetings of the allocation committee usually take place once a month. After the meeting, the DMRE informs the National Agency of Dams and large transmission Mains (ANBT) of the allocated quotas for each user. DAEP informs the Potable Water Supply Agency (ADE) with regard to the levels of potable water available; the water code stipulates that priority is given to potable water supply. DHA informs the ONID, Hydraulics Directorates of Provinces (DHW) and the Ministry of Agriculture (MADR) with regard to irrigation. ONID then contacts the dam manager in order to set the calendar of dam water release, in order to best serve the irrigation schemes. At this stage, there is poor coordination between ANBT and ONID regarding the program of water release, particularly if the dam serves two groups of users at the same time, e.g., agricultural and urban. Furthermore, according to DHA staff, there are problems with the data itself: the agencies sometimes provide unreliable data. In addition, there is a lack of coordination between agencies at the Ministry of Water Resources and the departments of other ministries that are in charge of monitoring. 


\subsubsection{At local and scheme levels}

The MADR informs the DSA (Directorate of Agricultural Utilities of the Provinces), which, in turn, informs farmers (Chamber of Agriculture) of quota availability. Farmers contact the ONID and organize themselves for the water release. Meanwhile, the Ministry of Water Resources instructs all the provinces with irrigation schemes to develop a monitoring committee for the irrigation season. This committee comprises representatives from the DHW, DSA, Chamber of Agriculture, and Regional ONID; they meet once a month in order to prepare for the irrigation season. Nevertheless, only the committee from Algiers province has been able to gather the farmers for their own education; the other provinces have not succeeded in this regard.

In addition, it should be mentioned that some farmers apply late for the use of water. Many farmers come to claim water during the irrigation season, after water is available in the network.

Once a date has been agreed upon by the DSA, farmers' association and Chamber of Agriculture, the DSA and ONID announce quota availability. Heads of scheme sections and ditch-riders spread the information to the farmers. Then, the farmers apply once more for the use of water and settle for variable rates of $50 \%$ to $100 \%$ of the total water charge. The agency allocates the water resources according to established criteria. First priority is given to perennial crops, i.e., orchards. Second priority is given to crops with low water consumption (some types of vegetable crops). If there is enough water remaining, it is allocated to the remaining crops. Irrigation proceeds from 7 am to $5 \mathrm{pm}$ (or longer), seven days a week. Nonetheless, at this stage, several constraints impede water management in the irrigation schemes, including:

* The misrepresentation of areas used by farmers still disrupts water distribution.

* Indebted farmers settle their debt only at the beginning of the irrigation season.

* Lack of irrigation system maintenance and poor water availability discourage farmers from starting their agricultural work on time.

* The theft of irrigation water persists in both schemes, causing serious financial damage to the agency. In the East Mitidja scheme, in 2006, more than 1.1 million $\mathrm{m}^{3}$ of water was stolen, which represents more than $23 \%$ of the total water losses, compared to an average of less than $20 \%\left(350,000 \mathrm{~m}^{3} /\right.$ year) from 1996 to 2005 .

* Difficulties in providing water to farms, particularly to subdivided collective farmland. The division of collective farmlands into peasants' personal plots led to disputes between members over the use of water resources [12].

* Access and water resource sharing remain unreliable for some farmers [12].

* Competition of farmers at the irrigation intake.

* The priority of irrigation given to the orchards causes jealousy among other farmers [12].

* Difficulties in estimating the volume consumed.

* Inadequacy of the irrigation system components with regard to farm configuration. The hydrants as well as the intake are no longer adequate for 
the new configuration of the subdivided collective farmlands, represented in both schemes. This resulted in an unreliable water supply and farmer dissatisfaction [12].

\section{Conclusion}

Algerian irrigation scheme management has been very limited and far from satisfactory. Water policy has not worked efficiently in terms of water allocation among users. The lack of coordination at the institutional and local levels has led to poor monitoring of scarce water-supply services. Furthermore, irrigation management issues are exacerbated by a lack of maintenance, the constraints of fee collection, water allocation system and land reform, low convenience efficiency, weak stakeholder involvement, and the indifference of local administrations. Reforms in the water sector that promote irrigation agency autonomy and cost recovery have yielded poor results. Indeed, both irrigation schemes are in a low equilibrium cycle.

The water policy in Algeria should move toward a water conservation approach that involves both supply- and demand-side management. The objective of the proposed strategy is to sustain the existing infrastructure and resources through a systematized program of repair, maintenance, and rehabilitation to improve performance and reduce water leakage. The maintenance of acceptable operating conditions represents a step toward recovering the cost of sustainability, facilitated by increasing plan allocations for maintenance, involving user groups in management, and appropriately pricing water to cover operation and maintenance costs.

Effective annual maintenance of the irrigation system will increase water flow and create reliable irrigation facilities. These measures will increase the irrigated area and the use of high input/high output cropping systems and enhance water productivity. These innovations could allow the farmers to pay more for water and recover the cost of water systems. However, the intensification of agriculture will require resistance to the pressures to urbanize agricultural land. In addition, water management should also be integrated into urban policy planning and management.

The actions necessary to improve irrigation management are as follows:

- Institutionalization of public-private partnerships in irrigation development.

- Promotion of participatory approaches in irrigation management and watersaving technology extension programs.

- Capacity development for both staff and farmers. Farmer education can increase awareness regarding water conservation as well as management capacity.

- Enhanced coordination between the water agencies and the municipalities.

- Better regulation of land ownership will contribute to improved management of natural resources.

- Adjustment of irrigation system components, such as hydrants, intake, etc. to the appropriate farm configuration. 
- Improvement of the billing system to recognize the particularities of each crop type.

- Development and promotion of affordable and appropriate irrigation technologies, particularly the use of water meters to improve accountability.

- Support of water police enforcement activities and measures to combat water theft.

- Involvement of the irrigation agency in groundwater management activities and legalization of the current illegal boreholes/wells for better monitoring of groundwater resources.

\section{References}

[1] Ministry of Water Resources, L'expression of 20/03/2008. Online: www.lexpressiondz.com/article/9/2008-03-20/50957.html

[2] Cleaver, K., The agricultural development of Algeria, Morocco, and Tunisia: A comparison of strategies for growth. Working paper SWP552. World Bank, 1982.

[3] Pérennès J. J., L'eau et les hommes au Maghreb. Karthala: Paris, 1993.

[4] World Bank., Algeria - Review of agricultural policies and agricultural services 1987 - 1993. Washington, DC. 1994.

[5] Conseil National Economique et Social, Problématique de développement agricole: éléments pour un débat national. $14^{\text {th }}$ session, national report. Alger, November 1999.

[6] Conseil National Economique et Social, L'eau en Algérie: Le grand défi de demain. $15^{\text {th }}$ session, national report. Alger, May 2000.

[7] Benmouffok, B., La prise en charge de l'irrigation en Algérie. La decentralisation et la gestion participative de l'irrigation. 4éme forum de la gestion de la demande en eau. Egypt, February 2003.

[8] Molden, David J. Sakthivadivel, R. Perry, Christopher J. de Fraiture, Charlotte Kloezen, Wim H., Indicators for comparing performance of irrigated agricultural systems. IWMI Research Report 20. Sri Lanka 1998.

[9] World Bank., Algeria-Public expenditure review: assuring high quality public investment. Main report Vol 1. Washington, DC. 2007.

[10] Laoubi, K. \& Yamao, M., Water pricing and the performance evaluation of irrigation schemes: the case of the Hamiz irrigation scheme, Algeria. Journal of Rural economics, Special issue. Tokyo, pp. 557-565, 2005.

[11] Programme d'Aménagement Côtier., Gestion intégrée des ressources en eau et assainissement liquide; Tendances et alternatives. PAC Zone côtière Algéroise, April, 2005.

[12] Laoubi, K. \& Yamao, M., A typology of irrigated farms as a tool for sustainable agricultural development in irrigation schemes: The case of the East Mitidja scheme, Algeria. International Journal of Social Economics, (36), 9. Emerald publisher. September, 2009. 